\title{
A consumer-orientated study of the South African beef value chain
}

\author{
Anita Labuschagne, Andre Louw \& Leah Ndanga ${ }^{1}$
}

\begin{abstract}
The South African beef industry, like many other South African supply chains, is challenged by the increased complexity and demand brought about by globalization, increased volumes and competition, shortage of skilled staff and pressures to meet changing customer needs. The power has shifted from the supply side to the consumer. The consumer has been empowered by greater knowledge. Consumer needs are changing. A combination of these two facts implies that not only the retailer, but also the supply chain as a whole must make sure that it is aligned to deliver customer value, in order to ensure sustainable competitiveness and survival, manage risks and ensure acceptable returns. Competition today is based on competing supply chains. The focus of this study is to define the South African consumer and their needs, so that the beef industry and in particular the supply chain participants, are able to identify opportunities to improve the delivery of customer value.

This study attempts to determine the extent to which the South African consumer needs and demands regarding beef have changed, and whether the beef value chain is positioned to meet these changes. The supply chain concept, market orientation, meat quality and consumer food trends form the theoretical framework of this study; an industry analysis provides the context in which agri-businesses function; a network analysis provides a better understanding of the roles and value-adding activities that are delivered by chain participants; and an analysis of the South African consumer establishes the composition of the market, consumer needs and disposable income issues that are critical to finding the optimal solution that is sustainable enough to meet the changing environment. Although the industry has a good status, good management practices can further increase consumer confidence in beef.
\end{abstract}

Keywords: South African beef, supply chain

\footnotetext{
${ }^{1}$ Respectively, MBA student, Professor \& PhD candidate: Department of Agricultural Economics, Extension and Rural Development, University of Pretoria
} 


\section{Introduction}

The purpose of this study is to determine the extent to which the South African consumers' needs and demands regarding beef have changed, and whether the beef value chain is positioned to meet those needs and demands. This paper draws extensively from an MBA thesis by the same author. The study seeks to establish whether the South African beef value chain can improve on the delivery of customer value and satisfaction through the implementation of market specific strategies that will realise greater profitability and competitiveness.

South African supply chains are challenged by the increasing complexity and demand brought about by globalisation, increased volumes and competition, the shortage of skilled staff and pressures to meet changing customer needs (Leonardi, 2007; Olivier, 2004:2). The beef industry is no exception in this regard. The industry has the additional burden of competing with a product that is a commodity ${ }^{2}$. Due to an ever-increasingly competitive environment globally and nationally, industries and firms are competing through their supply chains instead of on an individual level. The greatest benefit gained from this strategy is that a competing chain is not easy to copy and can therefore provide a significant competitive advantage (Thompson, Strickland \& Gamble, 2005:144).

The power in the supply chains has shifted from the supply side to the consumer. The consumer has been empowered by greater knowledge. Consumer needs are changing. A combination of these two facts implies that both the retailer and the supply chain as a whole must ensure that it is aligned to deliver customer value in order to ensure sustainable competitiveness and survival. South African consumers have diverse needs, of which the beef industry must take cognizance. The importance of customer orientation is presented in this paper as a means of establishing a sustainable competitive advantage. Competition today is based on competing supply chains and a thorough understanding of the beef network is necessary to understand the possibilities available when designing the optimal supply chain and network (Van Rooyen, 2002).

The theories of supply chain management and strategic management. The presentation of the supply chain concept, market orientation, meat quality and consumer food trends forms the theoretical framework of this study. The industry analysis clarifies the context in which agribusinesses function. The network analysis provides a better understanding of the roles and value-adding activities that are delivered by chain participants, and the analysis of the South African consumer aims to establish the composition of the market, consumer needs and disposable income issues. The different analyses are critical to finding an optimal solution that is sustainable enough to meet the changing environment. Industry-specific information regarding the structure and function of the beef value chain was gathered through interviews with industry leaders and experts. Specific consumer information was gathered through a consumer survey.

\footnotetext{
${ }^{2}$ A commodity, in the marketing sense, is still a product, but it's one sold primarily on a price basis due to a lack of differentiation features and benefits from its competitors, leaving the only competitive point as price. So a differentiated product reaches commodity when all of the competitive offerings are considered equal in the eye of the customer and further feature improvements, often intangible, for value-adding are not possible. This is the case with beef.
} 


\section{The SA Consumer}

Conducting an analysis of the South African consumer is needed in order to establish the composition of the market and consumer needs so as to make choices about what supply chain strategy to use to match customer value with the customer market (Simchi-Levi et al., 2000:213). In order to enhance customer satisfaction, it is critical to address customer needs and take a value chain approach (Schutte, 2006; Willemse, 2006b:8). Customer satisfaction is presented as a source of sustainable competitive advantage and the reason for the existence of the beef supply chain. Customer value is defined as the basis for customer satisfaction. Customer value is a combination of key market attributes such as products and services, quality, price and delivery. Enhanced value, as perceived by the customer, will lead to customer loyalty and will decrease the effects of competition (Thompson et al., 2005).

The South African consumer market is heterogeneous and consists of different races with different cultures and market segments with varying needs and preferences. Changes in the South African market are driven by a growing economy and population, as well as by the emerging black middle-class, or "black diamonds". The SA consumer market can be segmented through Living Standard Measure (LSM) categorisation. Studies indicated that the lower LSM groups spend a higher proportion of their disposable income on food than the higher income groups. The middle income groups tend to expend more on meat in proportion to their disposable income. The emerging black consumers are moving from the lower LSM groups toward the middle and higher LSM groups. The growing black diamond group is one of the major driving forces of the recent increase in per capita spending on beef. The high LSM groups are spending a lower proportion of their disposable cash income on food and meat (BFAP, 2009).

The majority of South African consumers are very price sensitive regarding beef purchases. Taljaard et al. (2006:4) state that SA meat demand is influenced by five factors, namely disposable income, own price of beef, meat price related to other products, changes in size and structure of the population and changes in consumers' taste and preferences. The first three factors are economic factors. Taljaard et al. (2006:6) found that the non-economic factors influencing demand are becoming more important than in the past.

\subsection{Consumer Trends}

The six most important worldwide consumer food trends are convenience, versatility, environmental and ethical issues, value for money, health consciousness and simplicity (BFAP, 2009).

One of the trends is a general worldwide increase in customer concern regarding health, diets and food safety. Internationally, this relates to issues such as traceability, animal welfare, diseases and production processes, sustainable agricultural practices, and naturally- and organically-produced beef. However, most South African consumers are generally less concerned about meat safety and animal welfare than their counterparts in other developed countries. Consumers still purchase meat from the informal sector such as street vendors and the informal, highly unregulated sector of unlawful slaughterings, which are highly vulnerable to meat safety concerns. The concerns of the South African consumer with regard to food safety, animal welfare and health consciousness are expected to increase over time (Loureiro \& Umberger, 2007:497). 
Concerns about animal welfare, sustainable agriculture and production, and health issues such as obesity are also on the rise (Grunert, 2006). Food labelling and trademarks may promote customer assurance to a large extent. Although organically-produced products form a significant international global food trend, this is a small niche market (FAS, 2000). The natural goodness of SA beef should be promoted to the consumer.

Another major trend is consumers' need for convenience. Convenience relates to all aspects regarding saving time and effort for the consumer. Although the SA consumer market differs from international markets, SA consumers' need for convenience corresponds to a great extent with international consumers' expectations (Thompson et al., 2005; Grunert, 2006).

Another trend is the consumers' need for versatility. The consumer wants to be able to eat a variety of meals, which relates to a variety of meat types and cuts, as well as preparation alternatives. Meat quality is evaluated based on information available about the meat, not only on the meat itself. Customers use intrinsic and extrinsic cues when determining meat quality. This provides opportunities for more differentiation of meat products, new requirements for the meat value chain in terms of delivering meat, and the provision of more information regarding the product. Grunert (2006) states that extrinsic cues will play a greater role in influencing the buying behaviour of the consumer in the future.

The needs of the customer form the basis for the existence of a supply chain. Knowledge of the different market segments and what constitutes customer value is the starting point of a successful business. The consumer of today has increased knowledge and power. Although the beef value chain is demand-driven, there are opportunities for delivering increased customer value and satisfaction. Supply chains must therefore be aligned to customer market segments (Thompson et al., 2005).

\section{The SA Beef Industry}

The SA beef industry is characterised by a duality in which the informal market constitutes 47 $\%$ (Booysen, 2007:79; NAFU, 2007:36). It has a highly developed commercial sector and an emerging sector (Vink \& Kirsten, 2003:3). The beef industry contributes to food security and the nutritional wellbeing of the South African population, as well as to the growth of the economy as a whole. Value-added activities in the meat industry include slaughtering, processing and preserving meat. The production of meat increased by $13.7 \%$ from 672000 tons in 2004/05 to 763.9 tons in 2005/06 (NDA, 2007:60). The consumption of beef increased by $5.7 \%$ from 15.4 kilogram per capita in 2005 to the 17.44 kilogram per capita of today. The income generated from the private consumption of meat was R51.857 billion in 2007, which constitutes an increase of $6.5 \%$ from 2005 (NDA, 2007:107). The increase in beef consumption can be attributed to good economic growth, population growth and the emerging black middle-class.

Schutte (2006) asserted that meat is the fastest growing agricultural commodity worldwide. South Africa is a net importer of beef. According to Booysen (2007:79), a large part of the emerging sector will need to commercialise as, without additional cattle supply from the emerging sector to formal marketing channels, it will be difficult for commercial agriculture to meet the targeted $6 \%$ annual growth. 


\subsection{Beef Characteristics}

The meat industry has had an abundance of bad publicity. Meat intake is associated with various forms of cancer, but the evidence is insubstantial (Hugo, 2005). Beef is a highly perishable product and the maintenance of the cold chain is therefore crucial to ensure product quality. The SA consumer prefers to purchase fresh (not frozen) meat, meaning there is only a short time to get products to the market. South African beef is slaughtered at a young age much younger than internationally. SA beef therefore has a lower cholesterol and fat percentage, making it one of the healthiest sources of beef in the world. Americans consume beef with an average fat content of 30 - 35\%. In South Africa, there is as little as $13 \%$ fat (Olivier, 2004:12; SAFA, 2010). The SA GRAINFED BEEF trademark is registered for the sole use of the members of the SA Feedlot Association in South Africa and its neighbouring countries. This beef has only a little over $1 \%$ marbling which means there is little or no fat to trim (SAFA, 2010). Meat quality influences consumer behaviour and spending, and consists of many dimensions. It is clear that non-economic factors and credence characteristics regarding meat are rising in importance (Booysen, 2006).

\subsection{Beef Supply Chain}

The SA beef supply chain combines a lean and an agile supply chain. Lean relates to the manner in which beef is produced and delivered to the retailer. This part encapsulates the producer, feedlot, abattoir and wholesaler, and links with the price sensitivity of consumers and competition with other meat types. The lean part of the supply chain also enables traceability and naturally-produced beef required by some consumers. The graphical presentation of the beef net chain illustrates the variety of supply chain linkages available. To a great extent, the characteristics of the beef product determine the supply chain. The partners in a successful, competitive beef supply chain are highly dependent on each other. Businesses have to carefully select the right supply chain configuration to optimally produce the desired customer value and satisfaction (Schutte, 2006; Booysen, 2007). The different consumer requirements have led to the registration of a number of South African beef brands. Traceability forms an integral part of branding and it is therefore important that the traceability system of a brand be firmly established and verified by an independent authority. SAMIC, with its accreditation by the Southern African Auditor and Training Certification Association (SAATCA) as auditors, has taken responsibility for the verification of registered trademarks/brands and represents audits on behalf of brand owners. SAMIC is also responsible for ensuring that these brands were applied correctly (SAMIC, 2008, 9).

Figure 1 illustrates that the South African beef market is a highly diverse network of linkages and different supply and value chains. The following role players are direct participants in delivering the product to market: the farmer/producer, feedlot, abattoir, wholesaler, processor, distributor and retailer. Other contributors and participants in the beef value chain are the providers of imports/exports, hides and skins; meat processors; providers of packaging, spices and other consumables. These participants are excluded from this study.

The beef supply chain is a cold chain and, to a large extent, the physical, inherent product characteristics determine the configuration thereof. The beef value chain has become increasingly vertically integrated (Food Pricing Committee Monitoring (FPMC), 2003:172). Integration is mainly driven by feedlots with their own abattoirs and wholesalers. Some feedlots sell directly to the consumer through their own retail outlets. 
Supply chain partners must be carefully selected; the target market segments must be taken as a starting point because businesses and the environment influence each other and form the supply chains and networks. Network analysis integrates the sequential value-adding activities, and also acknowledges the influence of horizontal relationships between firms that belong to a particular group or industry (Thompson et al., 2005; FPMC, 2003).

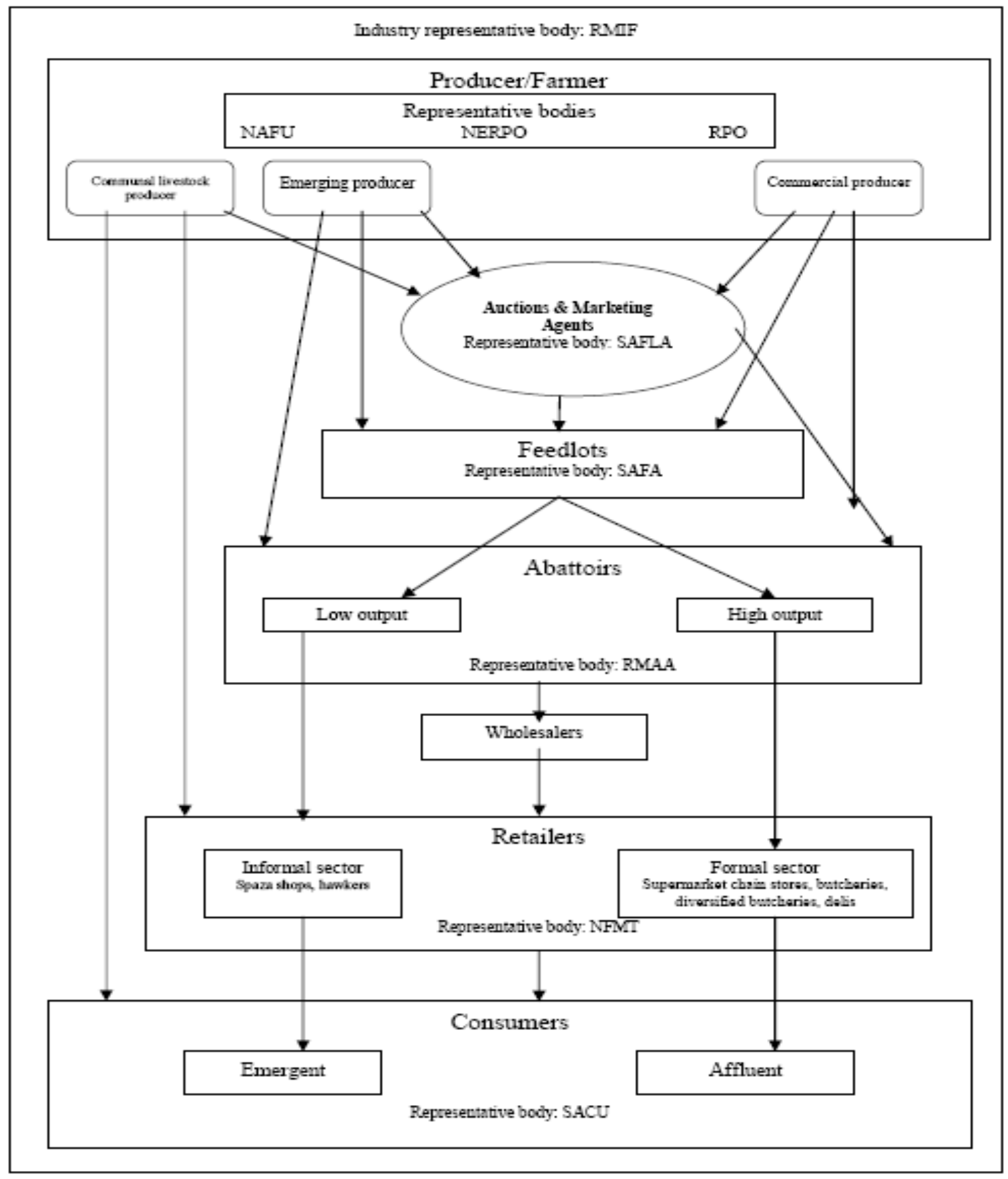

Figure 1: The South African Beef Net Chain

\subsection{Supply and Demand Trends}

Internationally and nationally, the consumption and production of meat is increasing. The general trend for red meat per capita consumption decreased from the 1970s until the late 1990s (Willemse, 2006a). Meat consumption moved sideways from the late 1990s to 2001. 
The consumption trend is upwards for beef and lamb, but downwards for pork between 2001 and 2007. The demand for meat is expected to increase worldwide by $16 \%$. Although beef demand is expected to increase by only $9 \%$ worldwide, it is expected to increase by $40 \%$ in developing countries (Schutte, 2006). The local consumption of beef exceeds the local production thereof. Beef consumption in 2005/2006 was 818000 tons. The production for the same period was 763900 tons and imports were 65000 tons (NDA, 2007:60).

South African agricultural production is switching away from field crops to meat as diets change (Willemse, 2006a; BFAP, 2009:4). Strong South African economic growth is driving the increase in meat demand. The beef herds in SA are in a building phase and imports contribute to the beef supply. The South African per capita income moved sideways from the early 1970s to the mid-1990s. Thereafter, there has been an upward trend in per capita income. The causes for this upward trend and changes in consumption patterns can mostly be attributed to the emerging black middle-class and good economic growth. According to Jooste (1996:87), per capita income remains the most important factor that influences the demand for beef in low income countries. However, in high income countries, factors such as diet and health concerns are more important than per capita income.

Beef not only competes with other red meats such as pork and lamb, but also with other protein sources, as well as protein replacements such as soya. According to Willemse (2006b), worldwide poultry is the most consumed meat, followed by pork. From 1996 to 2005, beef lost $3.2 \%$ of its global market share to poultry. In SA the growth in demand for chicken far exceeds that of beef. This trend can be attributed to consumers perceiving chicken as being cheaper, healthier and easier to prepare than beef. Generally, beef has a better boneto-meat percentage than chicken. Beef is in greater demand than pork, lamb and fish. Traditionally, beef is sold fresh to the consumer through various types of retail outlets. The consumer's need for convenience could lead to market share erosion as a result of ready-toeat and heat-and-eat meals (Olivier, 2004:5).

The South African consumer is extremely price sensitive when it comes to beef consumption. The per capita consumption of beef declined steadily from 1972/3 until 2000/1, which is largely attributed to the high red meat prices in comparison with white meat prices during this period (AC Nielsen, 2001:11). On the other hand, the per capita consumption of beef increased consistently from 2001/2002 until 2005/2006, from $12.34 \mathrm{~kg}$ per year to $17.44 \mathrm{~kg}$ per year (NDA, 2007:60). This positive trend is expected to continue.

\section{SWOT Analysis of the Beef Industry}

The industry analysis can be summarised by means of a SWOT (strengths, weaknesses, opportunities, threats) analysis, which is a descriptive as well as an analytical tool. Strengths and weaknesses relate to conditions internal to a business or industry, whereas threats and opportunities refer to external conditions facing the organisation or industry.

\subsection{Strengths}

SA consumers traditionally love beef that is tender and tasty. This preference is the biggest strength and asset of the beef industry. Other strengths include:

- SA traditions and customs ( biltong, braaivleis, rugby)

- Food safety

- Quality assurance 
- A good animal disease status

- A lean meat product

- A well-established commercial sector

\subsection{Weaknesses}

South African agricultural businesses battle to be competitive, due to the playing field not being level (Neethling, 2007; Schutte, 2007; Olivier, 2004). Factors that negatively influence competitiveness are:

- Other countries subsidise their farmers;

- There are unfavourable farming conditions compared to those of countries such as Brazil;

- The extent of SA legislation does not encourage fair competition;

- Problem animals causing damage need to be controlled efficiently to lessen the loss to the producer;

- SA lacks the capacity to commercialise developing producers;

- Basic good management practices are lacking in some of the industry sectors;

- Training and skills development are implemented too slowly;

- The implementation and control of good existing regulations are not uniform across national, provincial and municipal levels; and

- Consistency in terms of the classification system is an issue with regard to the differences in animal quality between the formal and informal sectors.

\subsection{Opportunities}

According to an AC Nielsen report (2001:36), there are several issues that can be used to build the beef industry:

- The nutritional value of beef;

- The monitoring of beef by an independent organisation (SAMIC) increases perceptions of beef safety;

- The majority of the SA population has the time to cook and enjoys doing so;

- The changing needs of consumers, lifestyle changes and expectations;

- Consumer confidence;

- Product value-adding and natural and organic production; and

- Emerging commercial farmers.

\subsection{Threats}

According to the AC Nielsen report (2001:36),Willemse, (2003 in Olivier, 2004) and Coetzee (2007:24), threats include:

- The affordability of beef;

- The perception that beef is unhealthy and may be unsafe to eat;

- The changing needs of the consumer provide opportunities, however, if these consumer needs are not adequately addressed, they may become threats;

- Security;

- Supply crisis;

- Natural resources

o Good agricultural land for grazing and animal production is limited

o Soil erosion and pollution

o Disasters such as drought, and losses due to the cold 
o The availability of water;

- Animal health and wellbeing;

- Increases in food prices;

- Import tariffs; and

- HIV and AIDS

\section{Key Findings}

The commercial South African beef value chain is a mature industry. Strong economic growth and the growth of the black middle-class drive the increased demand for beef. South Africa is traditionally a net importer of beef. Taking the increase in demand into account, an even shorter supply of beef is indicated. The future availability of beef is of great concern to industry participants. One solution is that the government, representative bodies and industry must work together to enable emerging beef producers to bring their cattle to the commercial market.

The main focus of this study was to answer the question of whether there are opportunities for the beef value chain to improve the delivery of customer value and satisfaction. Changes in customer needs and demands are the major drivers of change in the beef industry. In order to increase profitability and competitiveness, there must be a focus on value-based management systems and business structures; new pricing and trading policies; increased awareness of consumer needs; development and transfer of technology within the value chain; informal sector support programmes and integrated agri-value chain advocacy.

South Africa cannot compete globally, particularly with regard to price, due to highly unequal international "playing fields" (Van Rooyen, 2002). Some of the contributing factors to this situation are international subsidies, climatic conditions and legislation redressing past inequalities in South Africa. These factors are beyond the control of individual agribusinesses. South African agri-businesses will have to seek other means of competing successfully. The industry has to find sources of competitive advantage other than price. An increased market orientation delivering improved customer satisfaction can provide a sustainable competitive advantage for the supply chain participants.

The role of government is recognised in ensuring protection for the consumer through relevant regulations. Government must also provide an economic environment that is conducive to global competitiveness (Verbeke, 2000). The external agri-food environment is, to a large extent, hostile towards South African agri-businesses. Deregulation and democratisation created new challenges for agri-businesses. Issues such as land reform and redistribution of land, AgriBEE, labour laws, and macro-economic policy are negatively impacting on the commercial beef producer, stakeholders and other participants. The representative bodies of the channel participants need to influence government bodies to develop more appropriate regulations and policies, and to take a more positive stance with the commercial sector (Olivier, 2004:2; Day, 2009:1).

There is a worldwide drive for free trade, but free trade agreements do not protect developing countries. The current international shortage of meat is driven by bio-fuel developments and increased demand from developing countries such as India and China. Such shortages prevent meat-dumping in South Africa. However, in times of oversupply, South Africa is vulnerable to imports from countries that are heavily subsidised or produce meat more cost-effectively. 
The $40 \%$ ad valorem tariff on meat imports is necessary for the protection of the local beef industry. South African agri-businesses have to excel in producing meat superior to international meat products and do so more cost-efficiently (Olivier, 2004:.

Research and development are not currently high on the government's agenda. The beef industry has and must continue to drive research and development. The industry is lacking in relevant, up-to-date and reliable industry information and statistics. The statutory levies can be utilised to address this need of the beef value chain (Du Plessis, 2003 in Olivier, 2004:3).

South Africa has a good animal disease status and independent inspections of meat and cattle handling facilities ensure good quality beef and a high level of consumer trust. The Department of Agriculture assigned SAMIC the responsibility of ensuring that appropriate meat classification standards are applied in a uniform manner at those abattoirs that register voluntarily for the classification of their carcases (SAMIC, 2008:3). The beef classification system is unique and provides the basis for traceability. Factors that are under the control of agri-businesses need to provide a sustainable advantage. Refocusing on what will create additional value to the consumer might be the solution for creating sustainable competitive advantage (Van Rooyen, 2002).

The industry needs to promote the goodness of beef and address negative media coverage by presenting the correct facts. Booysen (2007) states that the generic marketing of beef rests on four pillars, namely enjoyment and appetite appeal, versatility and value, health and nutrition, confidence and assurance. The marketing levies should be used to promote the four pillars, as they are aligned to customer needs and preferences. Consumer marketing will help to build the positive image of beef. Branding, as a marketing tool, is becoming more important in the red meat industry and some suppliers have already successfully developed niche markets for their branded products.

At farm level, the producer will have to increase production efficiency, and face declining government support and an increase in global competition. The consumers' concern further adds to this burden, in that producers will have to find environmentally-friendly production methods of producing intrinsically safe meat. Some producers may choose to focus on the niche markets that show an interest in organic- and naturally-produced beef.

\section{Management Implications and Recommendations}

The beef market is heterogeneous and consists of many market segments. The starting point of a successful supply chain is the customer. Supply chain management provides solutions for many of the challenges facing the supply chain. The power has shifted from the supply side to the consumer. The consumer of today has been empowered with greater knowledge and power. In addition to this, the needs of the consumer are constantly changing. Although the beef value chain is demand-driven, there are opportunities for delivering increased customer value and satisfaction. Consumer trust in locally-produced fresh beef, good disease status, regulations, leanness and taste are the positive aspects on which the meat industry can build. A combination of these two facts implies that both the retailer and the supply chain as a whole must make sure that it is aligned to deliver customer value in order to ensure sustainable competitiveness and survival, manage risks and ensure acceptable returns.

Demands on agri-businesses will increase in the future. Businesses that want to survive and prosper therefore have to think creatively about solutions, be able to network, have good 
management skills and use up-to-date business intelligence. Consumer-orientated instead of production-orientated practices are the first prerequisite for a successful, profitable and sustainable business. Businesses should shift their strategies from focusing on comparative advantage to focusing on competitive advantage. Competitive advantage has to be established through the creation of unique products and processes aimed at differentiation.

Most solutions and opportunities in the beef industry can only be successfully addressed through a value chain approach, as the South African beef value chain is a highly interdependent cold chain. The supply chain partnerships and alliances are the second prerequisite for a successful agri-business. The commercial sector has a good idea of its customers' needs. Chain retailers and feedlots are working together to provide traceability and to provide customers with natural beef.

Consumer confidence in beef can be increased through good management practices from farm to fork, which includes animal handling before and after slaughter, meat quality, quality control, promotion and presentation of a healthy product, reasonable prices and knowledge transfer of how to use the product.

\section{Conclusions}

Strategy revolves around the art of positioning a company in the right place on the value chain: the right business, the right products and market segments, with the right value-adding activities (Normann \& Ramirez, 1993). Supply chain participants must take into account the major consumer trends as well as the needs of their specific market in establishing the correct supply chain configuration and business strategy. There are still many opportunities that can be addressed. Consumer trust in locally-produced fresh beef, good disease status, regulations, leanness and taste are the positive aspects on which the meat industry can build.

Three areas for potential further study were identified. The black diamond group is not homogeneous. Further studies into the needs and preferences of this group will be valuable. A study of the emergent beef market could help in better understanding the emerging sector. This knowledge would enable the industry to better assist with the development of this sector and in bringing their cattle into commercial marketing channels. Research is required into the future potential of communications, labelling and traceability as vehicles for consumer reassurance, and further research on the relationship between changing consumer behaviour and meat consumption patterns could provide additional valuable insights into new business opportunities.

\section{References}

AC Nielsen (2001). Business Needs Assessment report: South African Feedlot Association.

BFAP (2009). Bureau for Food and Agricultural Policy Baseline Report. The Bureau for Food and Agricultural Policy. Available from http://www.bfap.co.za. (Accessed 5 July 2009).

Booysen, M. (2007). Meer geleenthede vir vark. Landbouweekblad, 30 Maart 2007, p. 79. 
Coetzee, K. (2007). Making South African agriculture a better world competitor. Farmers weekly. 20 July 2007, p. 24.

Day, J. (2009). African Farmers Missing Out on the Global 'Livestock Revolution'. Press Release for STEPS Centre, Institute of Development Studies, University of Sussex, UK.

FAS. (2000). Implications of U.S. and global organic dairy, livestock and poultry production for international trade. Available from http://www.fas.usda.gov/dlp2/highlights/2000/organics/globproduction.html. (Accessed 7 July 2007).

FPMC. (2003). Food Pricing Monitoring Committee final report. pp. 172-194. Available from http://www.nda.agric.za/docs/fpmc/vol4-Chap4.pdf. (Accessed 4 December 2006).

Grunert, K.G. (2006). Future trends and consumer lifestyles with regard to meat consumption. Meat Science, Vol. 74, Issue 1, September 2006, pp. 149-160.

Hugo, A. (2005). Diet and red meat - is there a place for red meat in the modern diet? Available from http://samic.co.za/downloads/DietAndRedMeatzip. (Accessed 31 July 2007).

Jooste, A. (1996). Regional beef trade in Southern Africa. Unpublished MSc (Agric) thesis. Pretoria: University of Pretoria.

Labuschagne, A. (2007). A consumer orientated study of the South African beef supply chain. Unpublished MBA thesis, University of Pretoria. South Africa.

Leonardi, C. (2007). CEO`s hope shared strategic vision will ease global market demands. FMCG.co.za Retail. [Online] Available from http://www.fmcg.co.za/default.aspx?tabid=2302 [Accessed: 24 June 2007].

Loureiro, M.L. \& Umberger, W.J. (2007). A choice experiment model for beef: What U.S. consumer responses tell us about relative preferences for food safety, country of origin labelling and traceability. Food policy. Vol. 32, Issue 4, August 2007, pp. 496-514.

National African Farmers Union of South Africa (NAFU), (2007). Red meat market beckons. NAFU Farmer Trade. February Issue:2007.p36-37.

National Department of Agriculture (NDA), (2007). Abstract of Agricultural Statistics. Available from http://www.nda.agric.za. (Accessed 15 May 2007).

Neethling, G. (2007). Presentation at Excellence in Meat Management conference. 16 July 2007.

Norman, R and Ramirez, R. (1993). From Value Chain to Value Constellation: Designing Interactive Strategy. Harvard Business Review. Vol.71, July/August, pp. 65-77.

SAMIC (2008). Annual Report

Simchi-Levi, D., Kaminsky, P. \& Simchi-Levi, E. (2000). Designing and managing the supply chain. McGraw-Hill, New York, NY. 
Schutte, G. (2006). Kwessies in die groot en kleinveesektor en owerheids beleidsaspekte. Vleis Imbizo. 2 Maart 2006.

Schutte, G. (2007). Die rooivleiswaardeketting en die finansiering van noodsaaklike funksies. Presentation at National RPO congress. 22 June 2007.

Taljaard, P.R., Jooste, A. \& Asfaha, T.A. (2006). Towards a broader understanding of South African consumer spending on meat. Free State: Department of Agricultural Economics, University of the Free State.

Thompson, A.A., Strickland, A.J. \& Gamble, J.E. (2005). Crafting and executing strategy. Fourteenth edition. New York: McGraw-Hill Irwin.

Van Rooyen, C.J. (2002). Challenges for agri-business in the 2000's. In Agri-business - A source book for agri-business training, December, Vol. 4, pp. 119-126.

Verbeke, W. (2000). Influences on the consumer decision-making process towards fresh meat. British food journal, Vol. 102(7):522-538.

Vink, N. \& Kirsten, J. (2003). Agriculture in the national economy. In Nieuwoudt, L. \& Groenewaldt, J. , Challenge of Change. South Africa: University of Natal Press, pp. 3-19.

Willemse, J. (2006a). Supply and demand trends. Meat Imbizo presentation. 2 March 2006.

Willemse, J. (2006b). Verbruiker kom eerste. In Landbouweekblad, 31 Maart 2006, p. 8. 